\title{
Malgorzata Kozłowska
}

Uniwersytet Pedagogiczny

im. Komisji Edukacji Narodowej

w Krakowie

\section{Uwarunkowania rozwoju raftingu na Dunajcu jako nowego produktu turystycznego w Pieninach}

\section{Development conditioning of rafting on Dunajec River as a new tourist product in the Pieniny region}

\begin{abstract}
Streszczenie
Flisactwo pienińskie, które od poł. XIX w. przybrało formę unikatowej w skali Europy i świata atrakcji turystycznej, doczekało się w ostatnich latach znaczącej konkurencji. Stanowi ją stworzony przez przedsiębiorców nowy produkt turystyczny: rafting - rozumiany jako spływ pontonem z nurtem dzikich rzek górskich. Pomimo upływu kilkunastu lat od początków oferowania tego produktu przez firmy raftingowe rozwój tej atrakcji turystycznej nadal napotyka na organizacyjne i legislacyjne problemy. Są one związane z brakiem spójnej koncepcji działania oraz polityki społeczno-gospodarczej lokalnych organów samorządowych i jednostek pozarządowych oraz zainteresowanych instytucji i firm. Wyraźnie zarysowuje się tu brak jednostki czy instytucji, która przyjęłaby rolę koordynatora, co skutkuje regulacjami, które zamiast wspierać dynamiczny rozwój przedsiębiorczości raftingowej w regionie, mogą stanowić dla niego bariery.
\end{abstract}

\begin{abstract}
Traditional rafting has been developing on Dunajec River for over a thousand years. In the mid-1800s, it became a unique attraction on the European and worldwide scale. Recently, a significant competition has been established involving a white water rafting promoted by companies. Even though the white water rafting has been developing in this area for over a decade, it continuous to encounter both organizational and legislative obstacles. They result from a lack of integrated concept of actions and a socio-economic policy of the local government and non-governmental bodies, as well as involved institutions and companies. It is clear that an institution is needed to co-ordinate the industry, because the existing regulations fail to support a dynamic development of rafting companies in the region.
\end{abstract}

Słowa kluczowe: flisactwo pienińskie; produkt turystyczny; przedsiębiorczość; rafting Key words: entrepreneurship, tourism product; traditional wooden rafting in Pieniny region; rafting

\section{Wprowadzenie}

Flisactwo pienińskie, które uprawiane jest na rzece Dunajec od ponad tysiąca lat, od poł. XIX w. przybrało formę unikatowej w skali Europy i świata atrakcji turystycznej, na bazie której stworzony został regionalny produkt turystyczny Pienin. Dotychczas oferowana przez flisaków forma pokonywania urokliwego przełomu rzeki opiera się głównie na wrażeniach estetycznych związanych z podziwianiem w ciszy piękna krajobrazu, lecz z punktu widzenia aktywności 
fizycznej ma charakter bierny. Tymczasem styl życia współczesnego człowieka, oparty już nie tylko na modzie, ale coraz częściej na uświadomionej potrzebie podejmowania aktywności ruchowej, spowodował, że turyści oraz mieszkańcy regionu Pienin zaczęli poszukiwać nowych form korzystania z uroków rzeki. Także pojawiające się w Polsce pod koniec XX w. (okres przemian ustrojowo-gospodarczych) zapotrzebowanie na organizację imprez integracyjnych i motywacyjnych dla prężnie rozwijających się korporacji oraz dużych firm przyczyniło się do powstania wyspecjalizowanych firm raftingowych. $Z$ tego powodu z każdym rokiem oferta przedsiębiorców prowadzących działalność gospodarczą polegająca na organizowaniu spływów pontonowych i kajakowych stawała się bogatsza i w coraz większym stopniu zaspokajała potrzeby w tym zakresie. Pojawił się zatem na rynku nowy, konkurencyjny dla flisactwa pienińskiego produkt turystyczny. Celem niniejszego badania było przeanalizowanie determinantów tego produktu.

\section{Material i metoda badawcza}

Realizację zamierzonego celu osiągnięto przez analizę dostępnych danych statystycznych oraz obowiązujących aktów prawnych dotyczących badanego zjawiska, a także wywiady przeprowadzone z osobami pracującymi w instytucjach i podmiotach gospodarczych związanych z raftingiem: w Pienińskim Parku Narodowym, Polskim Stowarzyszeniu Flisaków Pienińskich oraz takich firmach raftingowych, jak: Retendo, Fun Time, Ski-Raft, Bagma Etreme, Rafting Pieniny. Własne badania ankietowe przeprowadzono w latach 2012-2013 wraz ze studentami kierunku Turystyka i Rekreacja na Uniwersytecie Pedagogicznym im. KEN w Krakowie na próbie 199 losowo wybranych mieszkańców regionu: Szczawnicy (80), Sromowiec Niżnych (29) i Wyżnych (18), Krościenka (31), Niedzicy (24) i Czorsztyna (17). Badaniu poddano 102 kobiety i 97 mężczyzn, według struktury wieku zaprezentowanej w tabeli 1, w tym zatrudnionych w turystyce 10 kobiet i 16 mężczyzn.

Tab. 1. Liczebność badanej populacji wg grup wiekowych

\begin{tabular}{|c|c|c|c|c|}
\hline Wiek & Do 25 lat & 26-40 lat & 41-60 lat & Powyżej 60 lat \\
\hline liczba badanych & 47 & 81 & 50 & 18 \\
\hline
\end{tabular}

Źródło: brak danych.

\section{Istota produktu turystycznego w kontekście flisu i raftingu pienińskiego}

Produkt turystyczny definiowany jest na wiele sposobów, gdyż jest zagadnieniem złożonym i dlatego powinien być rozpatrywany wieloaspektowo. Produkty turystyczne mogą mieć różny zakres (Altkorn, 1997) i należy je interpretować w dwóch wymiarach: horyzontalnym (ogólnym), rozumianym jako pogląd turysty, oraz wertykalnym, odnoszącym się do punktu widzenia konkretnego producenta (Middleton, 1996). I właśnie pod kątem tych dwóch aspektów podjęta została analiza raftingu jako nowego produktu turystycznego w Pieninach.

Coraz częściej w praktyce gospodarczej pojawia się pojęcie regionalnego produktu turystycznego, które staje się motywem przewodnim większości strategii opracowywanych przez miejscowości i regiony opierające swój rozwój na turystyce. Brak jednolitego rozumienia słowa region utrudnia także zdefiniowanie pojęcia regionalny produkt turystyczny, które często zastępowane jest wyrażeniem turystyczny produkt regionu (Zdon-Korzeniowska, 2009). Określając spływy Dunajcem mianem regionalnego produktu turystycznego, zastosowano interpretację Turowskiego (1998), który definiuje go jako ,ruch społeczny obejmujący działania mające na celu odkrywanie, utrzymywanie i rozwijanie wartości przyrodniczych, materialnych i kulturo- 
wych danej miejscowości, małego czy wielkiego regionu". W literaturze przedmiotu regiony turystyczne utożsamiane są najczęściej z obszarami administracyjnymi, np. województwami, jednak kulturowo i historycznie ugruntowane flisactwo pienińskie wpisuje się w przytoczoną powyżej interpretację pojęcia regionalnego produktu turystycznego, pomimo że dotyczy znacznie mniejszego obszaru niż powszechnie rozumiany region.

\section{Flisactwo pienińskie a rafting na Dunajcu}

Flisactwo pienińskie rozwinęło się z uwagi na lokalizację wiosek góralskich nad rzeką Dunajec, która wśród bezdroży pierwotnej Puszczy Karpackiej ok. tysiąca lat temu była niejednokrotnie jedyną drogą komunikacyjną. Rzeka ta była także źródłem pożywienia i terenem rybołówstwa. Do tego celu pierwotnie używano jednego, dużego czółna, wydłubanego z pnia potężnych rozmiarów świerka, jednak z biegiem czasu - gdy zaczęło brakować odpowiednio dużych drzew oraz z przyczyn praktycznych (duże czółna były zbyt ciężkie do holowania pod prąd) wyrabiano łodzie mniejsze i lżejsze i wiązano po dwie obok siebie. Z czasem zwyczajny spław drzewa i połów ryb w Przełomie Dunajca, dokonywane dla celów gospodarczych, przekształciły się w wyjątkową atrakcję turystyczną (Grywalski, 2009). Początek flisu na użytek turystyki datuje się na poł. XIX w., kiedy to gości z Zamku Dunajec w Niedzicy zwożono tratwami do Czerwonego Klasztoru, stamtąd zaś często przewożono kuracjuszy do szczawnickiego kurortu i wędrowców schodzących z Trzech Koron do Szczawnicy. Organizowane wówczas spływy przybierały formę spływu flotylli nawet kilkudziesięciu tratw, na czele której płynęła tratwa flagowa, a z zamocowanej na niej małej armaty strzelano na wiwat. Z uwagi na węgierskie pochodzenie Józefa Szalaya, właściciela Szczawnicy na przełomie XIX i XX w., flis stał się atrakcją o charakterze międzynarodowym.

Pierwotna, indywidualna forma organizowania spływów wraz z rosnącym natężeniem ruchu turystycznego w Pieninach musiała z przyczyn praktycznych i ekonomicznych przyjąć cechy bardziej zorganizowanej działalności. Powołane w 1934 r. przez flisaków z Czorsztyna, Krościenka, Szczawnicy oraz Sromowiec Niżnych i Wyżnych Polskie Stowarzyszenie Flisaków Pienińskich przyjęło rolę koordynatora, a później także monopolisty w zakresie organizowania tej wyjątkowej atrakcji. W 1936 r. stowarzyszenie miało już 148 członków (flisaków) i dysponowało dwoma stałymi przystaniami (w Czorsztynie i w Sromowcach Niżnych) oraz ustaliło zasady szkolenia i egzaminowania flisaków, które z niewielkimi zmianami przetrwały do dziś. Obecnie Polskie Stowarzyszenie Flisaków Pienińskich ma zarejestrowanych 482 flisaków, którzy dysponują ok. 250 tratwami. Stowarzyszenie nadal jest monopolistą w zakresie tej atrakcji i nie ma możliwości organizowania spławu tradycyjnymi tratwami poza stowarzyszeniem i obowiązującą tam kolejnością. Spływy Dunajcem tradycyjnymi tratwami dostępne są dla turystów co roku od początku kwietnia do końca października. Podczas 182. sezonu flisackiego w 2013 r. spłynęło tratwami 258931 osób (rekordowa liczba turystów uczestniczących w spływie Przełomem Pienińskim w jednym sezonie przekroczyła 285 tys.). $Z$ uwagi na różne ceny biletów (ulgowe oraz grupowe) obrót finansowy flisaków można szacować na 7-9 mln zł rocznie, co w stosunku do niedużego obszaru, którego dotyczy, stanowi istotne źródło utrzymania lokalnej społeczności.

Rafting ( $\mathrm{z}$ ang. raft - tratwa) rozumiana jest jako turystyczna odmiana spławu rzecznego (flisu) z wykorzystaniem różnego rodzaju tratw, łodzi, kajaków itp. (Wojtasik, Tauber, 2011), najczęściej charakterystycznych dla danego regionu. Szeroko rozumiany obejmuje wszelkie dyscypliny, począwszy od ekstremalnego sportu (kajakarstwo górskie), przez rekreacyjne (tzw. spływy na byle czym, hydrospeed) i turystyczne (spływy kajakowe i pontonowe, wycieczki na tratwach flisackich), uprawiane na rzekach i potokach górskich (Pilawski, 2005). Ostatnio najbardziej popularną wersją raftingu jest spływ pontonem z nurtem dzikich rzek górskich 
zaliczany do turystyki ekstremalnej (Kruczek, 2002). Rafting organizowany jest na rzekach o różnym stopniu trudności, odpowiednich do potrzeb i możliwości uczestników. Klasyfikuje się je w Międzynarodowej Skali Trudności Rzek Górskich WW (z ang. White Water, z niem. Weiß Wasser - biała woda) od I do VI, jednak stopnie te są tylko teoretycznym przybliżeniem trudności rzeki, gdyż zależy on również od pogody i poziomu wody w danym momencie.

Za prekursorów raftingu uważani są John Frémont ${ }^{1}$ oraz Horace H. Day ${ }^{2}$, którzy w 1842 r. postanowili zbadać niedostępne tereny Gór Skalistych, używając gumowej tratwy. Skomercjalizowaną formę rafting przybrał w latach 60. XX w. - gdy w Stanach Zjednoczonych Ameryki powstały pierwsze firmy organizujące spływy, a od połowy lat 80 . XX w. jest on identyfikowany globalnie jako usługa turystyczna i w wielu miejscach na świecie stał się jedną z głównych atrakcji turystyczno-rekreacyjnych o charakterze ekstremalnym.

W Polsce rafting w obecnej formie rozwija się dopiero od kilkunastu lat, jednak ciągle jest stosunkowo mało popularny, głównie ze względu na niewielką liczbę rwących rzek górskich o dostatecznej ilości przepływającej wody. W naszym kraju nie występują rzeki górskie, które osiągają najwyższy, VI stopień trudności. „Najtrudniejszą” polską rzeką (poziom WWV uznawany za nadzwyczaj trudny) jest Kamienna w Szklarskiej Porębie, a rafting jest uprawiany przede wszystkim na Dunajcu, w Przełomie Pienińskim, rzadziej na Popradzie oraz Białce (tylko kajaki górskie), a także na rzekach dolnośląskich: Białej Lądeckiej, Dzikiej Orlicy, Bystrzycy Dusznickiej i Nysie Kłodzkiej (przełom bardzki) w Kotlinie Kłodzkiej.

\section{Uwarunkowania prowadzenia działalności raftingowej w Pieninach}

$\mathrm{Na}$ Dunajcu zorganizowany rafting rozwija się od 2000 r., gdy Szkoła Kajakarstwa Górskiego i Raftingu Retendo zaczęła proponować turystom komercyjne spływy pontonowe. W tym czasie Polska nie była jeszcze w strefie Schengen ani nawet w UE, co powodowało utrudnienia w organizacji spływów, np. każdorazową konieczność zgłaszania Straży Granicznej imiennej listy uczestników z wyprzedzeniem 24-godzinnym. Dlatego początkowo spływy były dostępne głównie dla grup zorganizowanych, lecz z biegiem czasu, gdy przybywało chętnych do uprawiania tej formy turystyki i rekreacji oraz jej organizatorów, stały się dostępne także dla turystów indywidualnych. Niestety, Straż Graniczna nie prowadziła wówczas rejestru tych zgłoszeń i nie ma żadnych danych liczbowych dotyczących wielkości omawianego zjawiska. Według danych przekazanych przez Pieniński Park Narodowy (PPN) w 2013 r. ze spływów pontonowych i kajakowych Przełomem Dunajca korzystało ok. 10 tys. osób, a przychody obliczone na podstawie sprzedanych biletów i wniesionych opłat ryczałtowych wyniosły ok. 36 tys. zł netto, podczas gdy w 2012 r. w spływach uczestniczyło ok. 7 tys. osób, a przychody ze sprzedaży biletów za udostępnianie szlaku wodnego do spływów pontonowych i kajakowych wyniosły 24 tys. zł. netto. PPN nie dysponuje danymi dotyczącymi liczby biletów zakupionych przez osoby korzystające ze spływów pontonowych i kajakowych w poprzednich latach, ponieważ sprzedawane wówczas bilety były identyczne jak te dla spływających łodziami flisackimi. Wprowadzenie w 2012 r. innych, różniących się wielkością i grafiką biletów dla korzystających ze spływów pontonowych i kajakowych dało możliwość ich policzenia. Bilety sprzedawane są na przystaniach flisackich w Sromowcach Wyżnych-Kątach i Sromowcach Niżnych oraz w punkcie informacyjnym w dyrekcji PPN. W 2012 r. zezwolenie na prowadzenie działalności otrzymało 15 firm z różnych miejscowości: Krościenka, Nowego Targu, Nowego Sącza i okolic,

\footnotetext{
${ }^{1}$ John Frémont (1813-1890) - wojskowy (generał armii amerykańskiej), podróżnik, odkrywca.

${ }^{2}$ Horace H. Day (1813-1878) - potentat przemysłu gumowego w Stanach Zjednoczonych, projektant gumowej tratwy - prototypu współczesnego pontonu.
} 
Szczawnicy, Szlachtowej, Sromowiec Niżnych oraz Krakowa. Obowiązek uzyskania zezwolenia na prowadzenie działalności raftingowej został wprowadzony w 2012 r., dlatego PPN nie ma danych z lat wcześniejszych. W 2013 r. wydano 18 zezwoleń dla firm pochodzących z miejscowości wymienionych powyżej oraz Bochni i Czorsztyna. W samych Sromowcach Niżnych - miejscu rozpoczęcia trasy spływu - działają dwie stacjonarne firmy, pozostałe przywożą turystów i sprzęt ze Szczawnicy, Zakopanego, Krakowa, Krościenka, Nowego Targu, Bochni i Czorsztyna. Spływy pontonowe oraz kajakowe na Dunajcu organizują także Słowacy z drugiego brzegu rzeki. W miejscowości Czerwony Klasztor istnieje jedna prężnie działająca firma, która obsługuje ok. 5 tys. osób w sezonie (maj-październik) oraz dwie mniejsze spoza tej miejscowości, które obsługują kolejne 5 tys. klientów. Wobec powyższego (dane ze sprzedaży biletów do PPN i od słowackich przedsiębiorców, działalność w szarej strefie oraz spływy prywatne bez zakupionego biletu) szacuje się wielkość badanego zjawiska na 20 tys. osób w sezonie (co stanowi mniej niż 10\% turystów uczestniczących w spływach tradycyjnymi tratwami), które generują przychody dla firm raftingowych w granicach $1-1,5$ mln zł. Jak dowodzą M. Zdon-Korzeniowska i T. Rachwał (2011), turystyka okazała się być wrażliwa na współczesny światowy kryzys gospodarczy, jednak w Polsce przyniósł on stosunkowo niewielki regres, który w odniesieniu do flisactwa i raftingu na Dunajcu nie miał istotnego wpływu na kondycję tych przedsiębiorstw.

Najciekawszy dla organiatorów spływów pontonowych i raftingowych fragment Dunajca to Przełom Pieniński, który leży w granicach PPN, a co za tym idzie wszelka aktywność gospodarcza tam prowadzona podlega dodatkowym regulacjom, wynikającym ze statusu obszaru chronionego. Informacje zawarte poniżej zostały uzyskane od dyrekcji PPN, która stoi na stanowisku, że spływy Dunajcem są najmniej inwazyjną formą zwiedzania parku i że PPN nie dyskryminuje żadnego ze sposobów korzystania ze spływu, pod warunkiem przestrzegania regulaminu zwiedzania, m.in.: zachowania ciszy, niedobijania do brzegów Dunajca, niezaśmiecania rzeki i jej brzegów. Niestety, ponieważ przy organizacji raftingów ważniejsze są przeżycia związane ze spływem jako formą emocjonującej rekreacji niż podziwianie piękna przyrody, często dochodzi do łamania obowiązujących przepisów przez organizatorów oraz uczestników spływów pontonowych i kajakowych. Dlatego PPN przeprowadza regularne kontrole przestrzegania regulaminu przez wszystkich korzystających ze szlaku wodnego. Od 2012 r., zgodnie z 5 p. regulaminu dla turystów zwiedzających PPN, jednostki organizacyjne, osoby prawne i osoby fizyczne prowadzące działalność gospodarczą polegającą na organizacji spływów Przełomem Dunajca zobowiązane są do uzyskania zgody dyrektora PPN. Indywidualny spływ może zrobić każdy, kto ma własny ponton lub kajak, pod warunkiem wykupienia biletu na szlak wodny i przestrzegania regulaminu dla zwiedzających. Nie dotyczy to spływów z użyciem sprzętu wypożyczonego, wówczas spływ jest firmowany przez organizatora lub wypożyczającego, czyli podmioty prowadzące działalność gospodarczą. Kwestia opłat dla raftingu prywatnego (indywidualnego) i zorganizowanego (działalność gospodarcza) regulowana jest na podstawie Zarzadzenia Dyrektora Pienińskiego Parku Narodowego nr 2/2013 z dnia 11 kwietnia 2013 r. w sprawie wprowadzenia regulaminu dla zwiedzajacych oraz opłat za udostęnianie parku narodowego, dostępnego na stronie internetowej parku (www.pieninypn.pl). Turysta indywidualny jest informowany o aktualnych przepisach w tym względzie poprzez ww. stronę internetową PPN, a w okolicach przystani w Sromowcach Niżnych, przy głównej drodze, znajduje się tablica PPN informująca o konieczności wykupienia biletów za korzystanie ze szlaku wodnego w Przełomie Dunajca. Łamanie przepisów przez uczestników spływów pontonowych i kajakowych grozi mandatem karnym. Nieprzestrzeganie obowiązujących przepisów przez podmioty prowadzące działalność gospodarczą może skutkować mandatem, utratą zezwolenia 
na organizację spływów na obszarze PPN, a w niektórych wypadkach - procesem sądowym. Kontroli dokonuje Straż Parku, Policja i Straż Graniczna. Są one prowadzone wybiórczo, z różnym natężeniem, również przez łączone patrole ww. służb. Sprawdzane jest przestrzeganie obowiązujących przepisów, posiadanie biletów na szlak wodny oraz zezwoleń w wypadku firm organizujących spływy. Na terenie PPN nie można rozpocząć ani zakończyć spływu w dowolnym miejscu. Spływy pontonowe powinny rozpoczynać się i kończyć w punktach wyznaczonych w obrębie przystani lub w miejscach wskazanych przez wspólnoty wsi na ich obszarze. Takie miejsce zostało wyznaczone w Sromowcach Niżnych przez Spółkę dla Zagospodarowania Wspólnoty Gruntowej we wsi Sromowce Niżne. Niestety, organizatorzy raftingów nie zawsze przestrzegają tych zasad i rozpoczynają spływy poza wyznaczonymi miejscami. Na terenie PPN obowiązuje zakaz dobijania do brzegów. Dunajec jest rzeką graniczną i ze strony słowackiej nie ma żadnych specjalnych zarządzeń dyrektora PIENAP dotyczących raftingu, a osoby spływające pontonami są zobowiązane do przestrzegania regulaminu PIENAP i przepisów obowiązujących w strefie przygranicznej.

Wywiady przeprowadzone wśród przedsiębiorców prowadzących działalność raftingową w Pieninach oraz mieszkańców regionu wskazują, że obowiązujące przepisy nie regulują kompleksowo zasad prowadzenia tej działalności, co nie sprzyja rozwojowi nowego produktu, gdyż:

- istnieją firmy lub osoby organizujące systematycznie albo okazjonalnie komercyjne spływy, pozostając w szarej strefie (brak zezwolenia dyrektora PPN, brak zgłoszenia działalności gospodarczej);

- sposób szacowania ryczałtu planowanej liczby sprzedanych biletów wstępu do PPN jest niesprawiedliwy, gdyż faworyzuje firmy rozpoczynające działalność w stosunku do tych kontynuujących działalność;

- przeprowadzane przez PPN kontrole są tendencyjne, ukierunkowane na sprawdzanie firm legalnie i systematycznie działających w stałym miejscu i o jednej porze; brakuje częstych i wyrywkowych kontroli o różnych porach dnia i w różnych miejscach, które spowodowałyby wyeliminowanie firm działających bez zezwoleń;

- brak wyznaczonego przez samorząd szczawnicki miejsca zakończania spływów komercyjnych i indywidualnych (brak oficjalnej zgody na korzystanie z przystani flisackiej przy moście w Szczawnicy ani innego wskazanego miejsca zmusza większość rafterów do nielegalnego korzystania z przystani flisackiej, co grozi karami lub w wypadku firm zmusza do poszukiwania odpowiednich miejsc do wydzierżawienia);

- informacja zamieszczona na stronie internetowej Pienińskiego Parku Narodowego oraz niepozorna tabliczka ustawiona na parkingu w Sromowcach Niżnych, informująca o konieczności zakupu biletu wstępu na szlak wodny dla turystów indywidualnych, nie są wystarczające i wielu turystów nieświadomie nie wnosi opłaty za bilet;

- pomimo statusu parku transgranicznego brakuje jednolitych przepisów dotyczących opłaty za korzystanie ze szlaku wodnego na Dunajcu w PPN i w PIENAP (Słowacy nie pobierają żadnych opłat, co stanowi zasadniczy problem dla Straży Parku w egzekwowaniu obowiązujących przepisów);

- kwestia wnoszenia opłat za korzystanie ze szlaku wodnego zarówno przez turystów indywidualnych, jak i firmy budzi kontrowersje, szczególnie w kontekście braku takiej opłaty po stronie słowackiej; można zatem wysnuć wniosek, że wystarczy rozpocząć spływ ze słowackiego brzegu, aby uniknąć dodatkowych kosztów, co w wypadku firm słowackich daje im przewagę konkurencyjną na wolnym, europejskim rynku; 
- monopolistyczna postawa Polskiego Stowarzyszenia Flisaków Pienińskich (pomimo deklaracji pozytywnego stosunku do raftingu) jest powszechnie znana z jawnej niechęci do firm raftingowych, które wg opinii większości flisaków stanowią dla nich szybko rosnącą konkurencję; dodatkowo flisacy sprzyjający rafterom lub planujący podjęcie pracy jako instruktorzy raftingu albo też otwarcie własnej działalności rafterskiej są negatywnie postrzegani przez hermetyczne środowisko flisackie; firmy organizujące komercyjne spływy pontonowe i kajakowe wskazują na brak możliwości realnej współpracy ze stowarzyszeniem w zakresie udostępnienia rafterom i kajakarzom górskim przystani flisackich lub choćby możliwości przejścia i dojazdu przez ich teren do innego miejsca w Sromowcach Niżnych i Szczawnicy. Przeprowadzone badania ankietowe wykazały, że stosunek społeczności lokalnej - zarówno kobiet, jak i mężczyzn - do nowej aktywności turystyczno-rekreacyjnej na Dunajcu jest obojętny $(50,8 \%)$ lub pozytywny $(44,7 \%)$, chociaż procentowo więcej kobiet uważa, że to pozytywne zjawisko. Osoby wykazujące pozytywne nastawienie do raftingu uważają, że jest to nowa, ciekawa forma rekreacji, przyciągająca turystów (ryc. 1). Jednak 4,5\% badanych (7 mężczyzn i 2 kobiety), w szczególności sami flisacy lub ich rodziny, stoją na stanowisku, że nowa forma spławu na rzece w parku narodowym powoduje nasilenie niekontrolowanego ruchu, co stwarza niebezpieczeństwo na wodzie oraz uniemożliwia skuteczną ochronę środowiska.

Ryc. 1. Stosunek mieszkańców rejonu Pienin (wg płci) do nowego produktu turystycznego - raftingu na Dunajcu

\section{Czy to dobrze, że splywy pontonowe są organizowane na Dunajcu?}

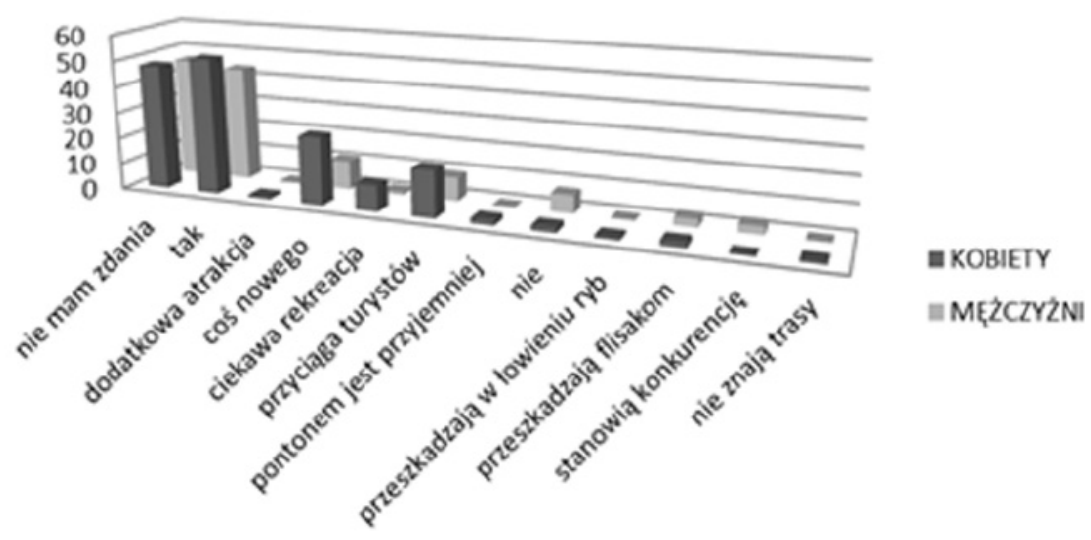

Źródło: opracowanie na podstawie badań własnych przeprowadzonych w 2012 r.

Analiza odpowiedzi badanych z różnych grup wiekowych ujawniła, że stosunkowo więcej młodych ludzi, w wieku do 25. roku życia, uważa, że to dobrze, że rafting rozwija się na Dunajcu niż że nie mają zdania na ten temat. Podczas gdy w grupie wiekowej 26-40 lat jest odwrotnie (ryc. 2).

Duża część respondentów $(53,8 \%)$ nie ma zdania w sprawie określenia wpływu raftingu na rozwój miejscowości, w której mieszka. Tymczasem 30,15\% badanych uważa, że rafting w sposób bardzo istotny lub istotny sprzyja rozwojowi funkcji turystycznej i rekreacyjnej regionu. Zaledwie $6 \%$ badanych upatruje w tej formie rekreacji negatywny wpływ na ten rozwój (ryc. 3). 
Ryc. 2. Stosunek mieszkańców rejonu Pienin (wg wieku) do nowego produktu turystycznego raftingu na Dunajcu

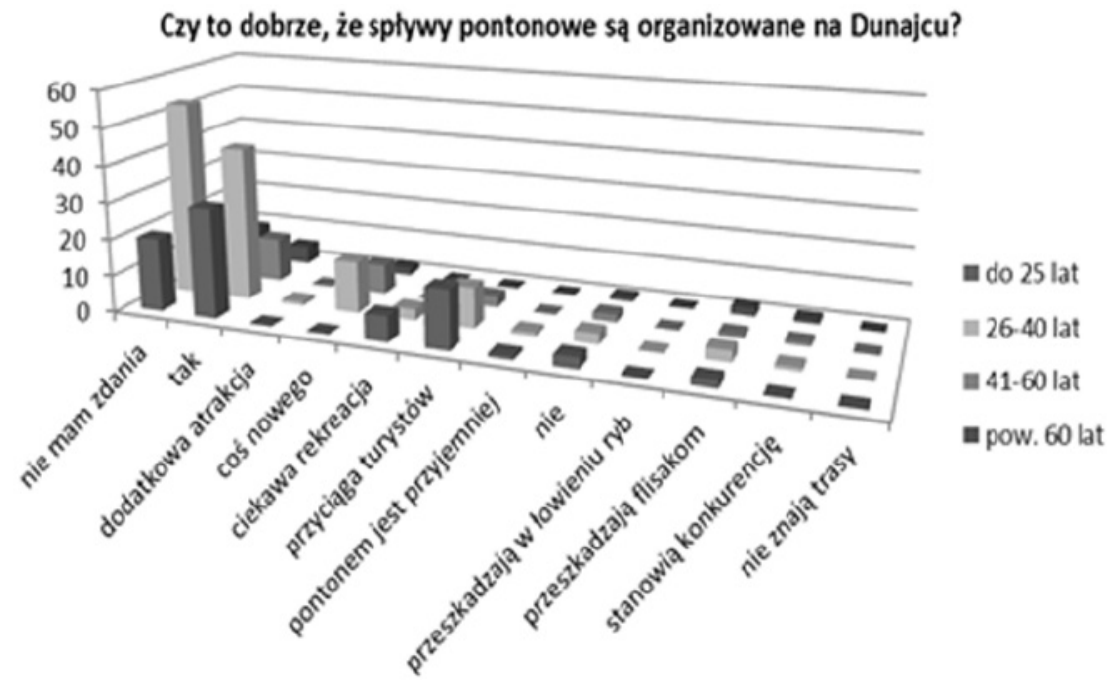

Źródło: badania własne przeprowadzone w latach 2012-2013.

Ryc. 3. Wpływ raftingu na Dunajcu na rozwój regionu Pienin wg mieszkańców w ujęciu kobiety mężczyźni

\section{Czy rafting ma wpływ na rozwój miejscowości?}

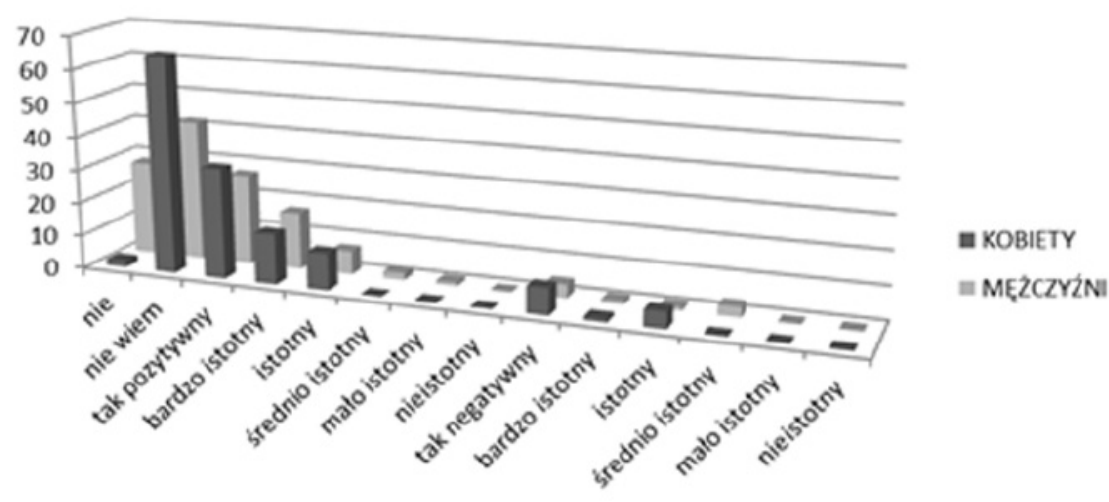

Źródło: badania własne przeprowadzone w latach 2012-2013.

Wśród młodzieży do 25 . roku życia 36,2\% badanych uważa, że rafting nie ma wpływu na rozwój ich miejscowości, natomiast 42,6\% nie wie, czy taki wpływ istnieje. Także 65,4\% osób w wieku 26-40 lat nie wie o takim wpływie, podczas gdy zaledwie 14,8\% badanych w tej grupie wiekowej uważa, że go nie ma (ryc. 4). 
Ryc. 4. Wpływ raftingu na Dunajcu na rozwój regionu Pienin wg mieszkańców w ujęciu grup wiekowych

\section{Czy rafting ma wpływ na rozwój miejscowości?}

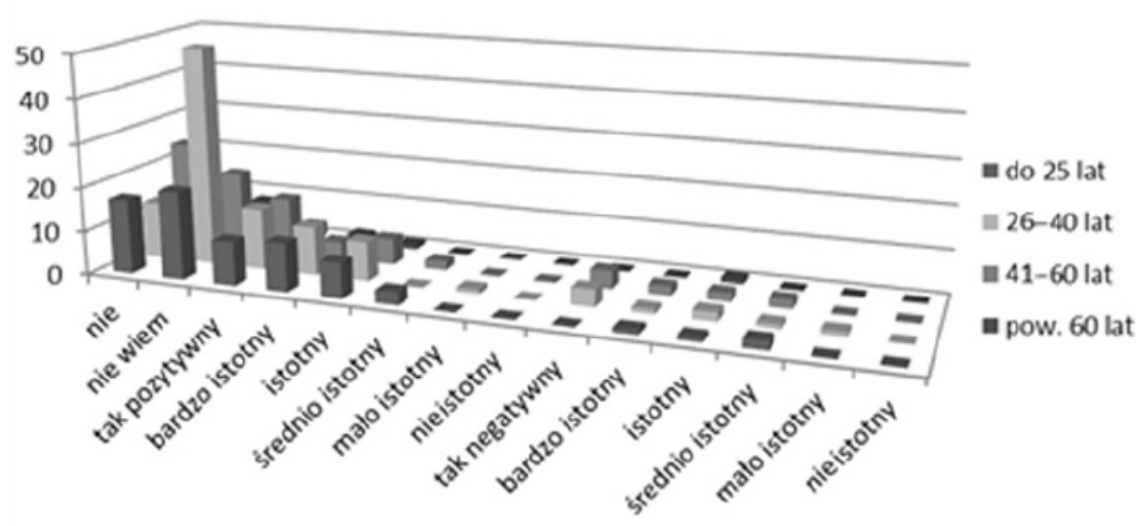

Źródło: badania własne przeprowadzone w latach 2012-2013.

\section{Podsumowanie}

W przeciwieństwie do tradycyjnego spływu tratwami, który można traktować jako regionalny produkt turystyczny - szczególnie z uwagi na jego kulturowe i przyrodnicze dziedzictwo - rafting na Dunajcu jest nowym produktem turystycznym przedsiębiorstw, wytwarzanym przez podmioty podaży rynku turystycznego, mogące oferować produkty pojedyncze lub ich pakiety (Altkorn, 1991). Przedsiębiorcy zidentyfikowali niszę na rynku usług w zakresie organizacji raftingu na Dunajcu i od 2000 r. systematycznie ją wypełniali, dochodząc w 2013 r. do liczby 18 firm. Pomimo upływu 13 lat realizacja oferowanego przez przedsiębiorców nowego produktu turystycznego nadal napotyka na organizacyjne i legislacyjne problemy, związane z brakiem spójnej koncepcji działania oraz polityki społeczno-gospodarczej lokalnych organów samorządowych, instytucji i jednostek pozarządowych oraz sektora usług. Wyraźnie zarysowuje się tu brak jednostki czy instytucji, która przyjęłaby rolę koordynatora, co skutkuje regulacjami, które zamiast wspierać dynamiczny rozwój przedsiębiorczości raftingowej, mogą stanowić dla niego ograniczenia. Zidentyfikowana powyżej sytuacja wpisuje się we wnioski sformułowane przez Zdon-Korzeniowską (2009) na podstawie przeprowadzonych badań empirycznych. Wykazały one, że działania polskich samorządów regionalnych na rzecz kształtowania regionalnych produktów turystycznych skupiają się na promocji, a inne zadania realizowane są w niepełnym lub bardzo ograniczonym wymiarze. Także badania nad produktami turystycznymi Piwnicznej i Szczawnicy oraz rozwojem przedsiębiorczości prywatnej, realizowane przez zespół badaczy pod kierunkiem Bednarczyk (2002), pozwoliły zdiagnozować tzw. lukę niedopasowania. Polega ona na niedopasowaniu między potrzebami małych i średnich przedsiębiorstw a polityką władz lokalnych, wspierającą przedsiębiorczość turystyczną na poziomie regionalnym. W kontekście zaprezentowanych powyżej wyników badań oraz analizy aktualnego stanu badanego obszaru nasuwa się wniosek, że pomimo upływu dekady luka niedopasowania nadal tam istnieje. Także aktualny, dotychczas niezrealizowany, pozostaje postulat Dryglas i Wacha z 2007 r. mówiący, że ,wobec dynamiki zmian w otoczeniu, w tym również regionalnym oraz aktualnych potrzeb przedsiębiorców lokalni decydenci będą zmuszeni do stałego monitoringu oraz aktualizacji swoich działań na rzecz wspierania przedsiębiorstw turystycznych”. 


\section{Literatura \\ References}

Atlkorn, J. (1991). Polityka produktu turystycznego. Kraków: Wydawnictwo AE, 9.

Atlkorn, J. (1997). Marketing w turystyce. Warszawa: PWN.

Bednarczyk, M. i in. (2002). Ekologiczna kolejka górska elementem zrównoważonego rozwoju regionu turystycznego w Polsce, w ramach projektu Europejska Inicjatywa EUREKA E! RAIL MOUNT. Kraków: Uniwersytet Jagielloński (maszynopis powielony).

Dryglas, D., Wach, K. (2007). Klimat dla rozwoju przedsiębiorczości turystycznej w Małopolsce w świetle badań empirycznych, Przedsiębiorczość - Edukacja, 3, 50.

Grywalski, A. (2009). Z historii spływu Dunajcem, Prace Pienińskie, 19.

Kruczek, Z. (2002). Kompendium pilota wycieczek. Kraków: Proksenia.

Middleton, V.T.C. (1996). Marketing w turystyce tł. Nalazek. Warszawa: Polska Agencja Promocji Turystyki.

Pilawski, A. (2005). Rafting jako forma turystyki, Zeszyty Naukowe WSG w Bydgoszczy, seria: Turystyka i rekreacja, t. 2, 265.

Turowski, J. (1998). Regiony - regionalizm - lokalizm. W: Czym jest regionalizm? Materiaty IV Kongresu Regionalnych Towarzystw Kultury. Radom 23-26.09.1998 r.

Wojtasik, L., Tauber, R.D. (2011). Turystka i rekreacja we wspótczesnym świecie. Poznań: Bogucki Wydawnictwo Naukowe.

Zarządzenie Dyrektora Pienińskiego Parku Narodowego nr 2/2013 z dnia 11.04.2013 r.

Zdon-Korzeniowska, M. (2009). Jak kształtować regionalne produkty turystyczne? Teoria i praktyka. Kraków: Wydawnictwo Uniwersytetu Jagiellońskiego.

Zdon-Korzeniowska, M., Rachwał, T. (2011). Turystyka w warunkach światowego kryzysu gospodarczego. Prace Komisji Geografii Przemysłu Polskiego Towarzystwa Geograficznego, 8, 126.

Małgorzata Kozłowska, dr, Uniwersytet Pedagogiczny im. Komisji Edukacji Narodowej w Krakowie, Instytut Geografii, Zakład Turystyki i Badań Regionalnych.

Absolwentka kierunku turystyka w Akademii Wychowania Fizycznego w Krakowie, doktorat z nauk o kulturze fizycznej, bogate doświadczenie zawodowe w szeroko rozumianej turystyce, zainteresowania badawcze w zakresie antropomotoryki i aktywności fizycznej oraz turystyki i edukacji eksperymentalnej poprzez wyprawy i podróże.

Malgorzata Kozlowska, PhD, Institute of Geography, Department of Tourism and Regional Research, Pedagogical University of Cracow, Poland.

A tourism graduate of the Academy of Physical Education in Krakow, a PhD in Physical Education. She has a wealth of professional experience in the field of tourism at large, her research relates to antropomotorics, physical activity and tourism, as well as experimental education through travelling and expeditions.

Adres/Address: $\quad$ Uniwersytet Pedagogiczny im. Komisji Edukacji Narodowej w Krakowie Instytut Geografii

Zakład Turystyki i Badań Regionalnych

ul. Podchorążych 2,

30-084 Kraków, Polska

e-mail:mkozlowka@up.krakow.pl 